\title{
DEVELOPMENT OF UV SPECTROPHOTOMETRIC METHOD FOR THE DETERMINATION OF BENIDIPINE HYDROCHLORIDE BY USING QUALITY BY DESIGN (QbD) APPROACH
}

\author{
MANISH KUMAR*, AJAY KUMAR SHUKLA, RAM SINGH BISHNOI, C. P. JAIN \\ Department of Pharmaceutical Sciences, Mohanlal Sukhadia University, Udaipur, Rajasthan, India \\ Email: manishsip@gmail.com
}

Received: 09 Apr 2018, Revised and Accepted: 24 May 2018

\begin{abstract}
Objective: To develop a simple, rapid, accurate, robust and inexpensive spectrophotometric method for the estimation of benidipine hydrochloride by using quality by design (QbD)" approach.

Methods: A UV spectrophotometric method was developed on Shimadzu UV-1800 double beam spectrophotometer using methanol as solvent and wavelength of $236 \mathrm{~nm}$ was selected as absorbance maxima ( $\lambda$ max). Effect of input variables on spectrum characteristics were studied for the selection of critical parameters and proposed method was validated for various parameters like system suitability, linearity, precision, accuracy, detection limits and quantification limits as per the International Conference on Harmonization guidelines ICH Q2(R1).

Results: Linearity of the method was found to be excellent over the concentration range 3 to $18 \mu \mathrm{g} / \mathrm{ml}$ with high correlation coefficient value of 0.9999. Limits of detection and quantification were found to be $0.20 \mu \mathrm{g} / \mathrm{ml}$ and $0.60 \mu \mathrm{g} / \mathrm{ml}$ respectively. The mean recovery was found to be 100.35 $\%$ with low percentage relative standard deviation (\% RSD) value. The precision study also has shown low \% RSD value ( $<1$ ). No interfering peaks were observed during specificity studies.
\end{abstract}

Conclusion: Obtained result indicated that the developed spectrophotometric method is robust and efficient for the determination of benidipine hydrochloride.

Keywords: Quality by design, Analytical quality by design, Benidipine hydrochloride estimation, Analytical method validation, Spectrophotometric estimation

(C) 2018 The Authors. Published by Innovare Academic Sciences Pvt Ltd. This is an open access article under the CC BY license (http://creativecommons.org/licenses/by/4.0/) DOI: http://dx.doi.org/10.22159/ijap.2018v10i4.26623

\section{INTRODUCTION}

The benidipine hydrochloride (BEN) is a calcium channel blocker. It is used orally as an anti-anginal and antihypertensive agent. Its chemical name is $( \pm)-\left(\mathrm{R}^{*}\right)-3-\left[\left(\mathrm{R}^{*}\right)-1\right.$-benzyl-3-piperidyl] methyl 1,4dihydro-2,6-dimethyl-4-(m-nitrophenyl)-3,5-pyridine dicarboxylate hydrochloride [1].

Concept quality by design (QbD) is used for the development of pharmaceutical processes to ensure a predefined product quality [2]. $\mathrm{QbD}$ concepts are explained in International Conference on Harmonization (ICH) guidelines Q8 (R1) (Pharmaceutical Development), Q9 (Quality risk management), and Q10 (Pharmaceutical quality system) [3-5]. ICH Q8 (R1) guideline defines QbD as "a systematic approach to development that begins with predefined objectives and emphasizes product and process understanding and process control, based on sound science and quality risk management" [6]. QbD is a systematic approach to product development through an understanding of the effects of various input variables (e. g. process parameters, materials) on the final product (active pharmaceutical ingredient or drug product). Thus, QbD approach defines appropriate ranges of the input parameters within which the quality of the final product is assured [7]. In a similar manner for analytical methods, QbD approach involves a full understanding of how the analytical technique attributes and operating conditions affect the analytical performance. Factors to study in" analytical quality by design" (AQbD) approach may include the type of analytical technique chosen, reagents used, and instrumental parameters [8].

There are similar advantages of applying QbD principles to analytical methods as to manufacturing processes and product [9]. Several researchers have implemented QbD principles to analytical methods development process [10-15]. AQbD approach can be used in the development of a robust and cost-effective analytical method which is applicable at any stage of the lifecycle of the product. Some regulatory authorities have recently provided flexibility of changing analytical method without revalidation if the AQbD approach has been implemented during analytical method development [16].
The first stage of $A Q b D$ approach is to set an analytical target profile (ATP) for the method. ATP defines the goal of the analytical method development process and it is the indicators of method performance. ICH guidelines on validation of analytical procedures, ICH Q2(R1), has given various method performance characteristics for an analytical method [16]. Thus, a QbD based UV spectrometric method can be developed by considering the ICH guidelines Q2 (R1).

The goal of the present investigation was to developed a simple, rapid, robust, flexible and economical UV spectrometric method for the estimation of benidipine hydrochloride by using analytical quality by design (AQbD)" approach. For implementing QbD approach to UV spectrophotometric analytical method, the effect of method input variables on spectral shape, intensity of absorbance, and absorbance maxima ( $\lambda \max$ ), were studied and critical parameters were selected for the proposed method. Then proposed method was validated as per the ICH guidelines ICH Q2(R1).

\section{MATERIALS AND METHODS}

\section{Equipment and chemicals}

UV Spectrophotometer (Shimadzu UV-1800 double beam spectrophotometer). Benidipine hydrochloride (BEN) was purchased from Niksan pharmaceutical Ahmedabad, India. All other chemicals used were of analytical reagent grade.

\section{Preparation of stock and working solution}

The solubility of BEN in different solvents such as distilled water, $0.01 \mathrm{~N}$ sodium hydroxide, $0.01 \mathrm{~N}$ hydrochloric acid, and methanol was determined. The maximum solubility of BEN was found to be in methanol. Hence methanol is used for the preparation of standard stock and working solutions. The stock solution was prepared by dissolving $25 \mathrm{mg}$ of BEN in $25 \mathrm{ml}$ methanol to obtain $1000 \mu \mathrm{g} / \mathrm{ml}$ concentration. Standard working solution of $10 \mu \mathrm{g} / \mathrm{ml}$ was prepared from stock solution by dilution and used for initial spectral scan in the UV spectrophotometer. 


\section{Determination of wavelength of maximum absorption}

Standard working solution $(10 \mu \mathrm{g} / \mathrm{ml})$ of BEN was scanned from 200-400 nm in the UV spectrophotometer for the selection of analytical wavelength. BEN showed maximum absorbance $(\lambda \max )$ at $236 \mathrm{~nm}$ (fig. 1). Hence $236 \mathrm{~nm}$ was selected as analytical wavelength.
Implementation of $\mathrm{AQbD}$ approach in the development of the analytical method

For AQbD approach, Ishikawa diagram was used to study the relationship between variable input parameters and the method performance characteristics of the spectrophotometric analytical methods [8] (fig. 2).

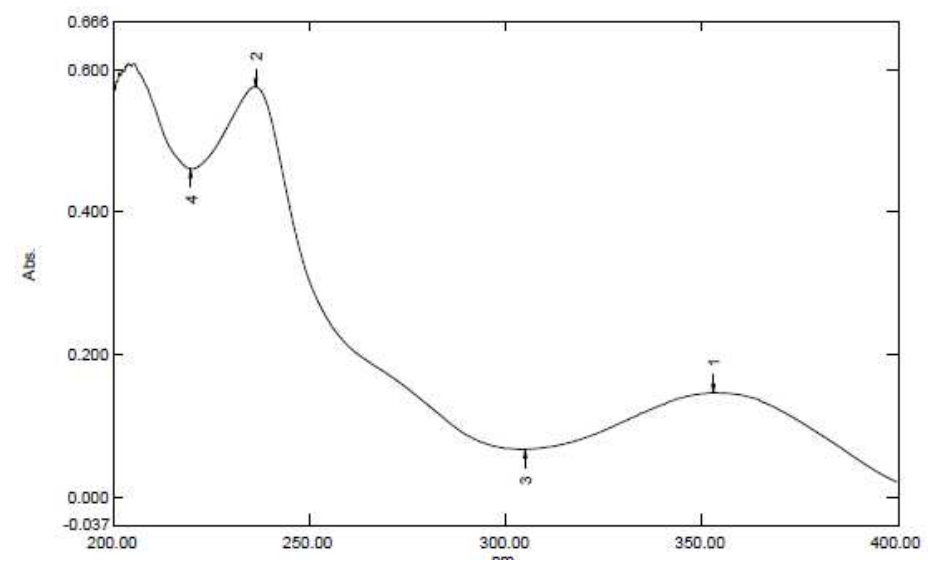

Fig. 1: UV spectrum of benidipine hydrochloride showing maximum absorbance ( $\lambda \max )$ at $236 \mathrm{~nm}$

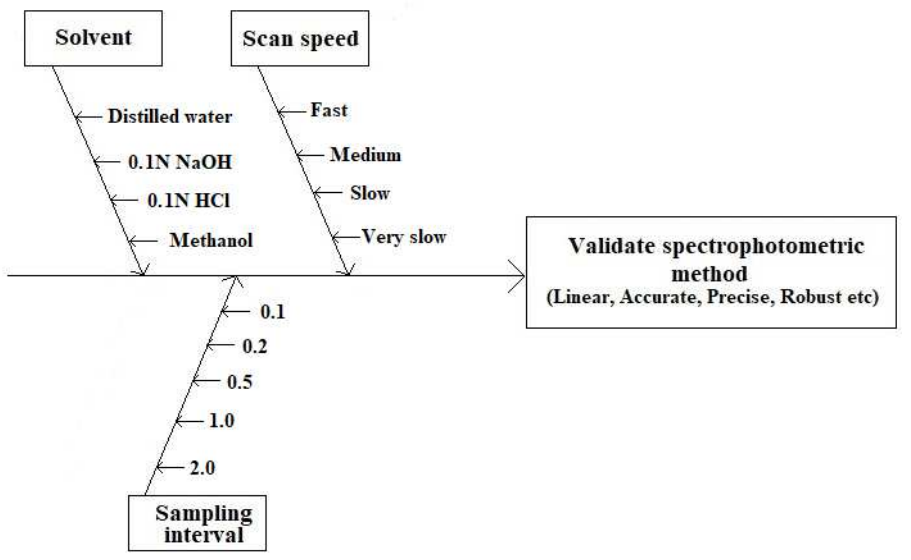

Fig. 2: Ishikawa diagram showing the relationship between variable input parameters and the method performance characteristics of the spectrophotometric analytical methods

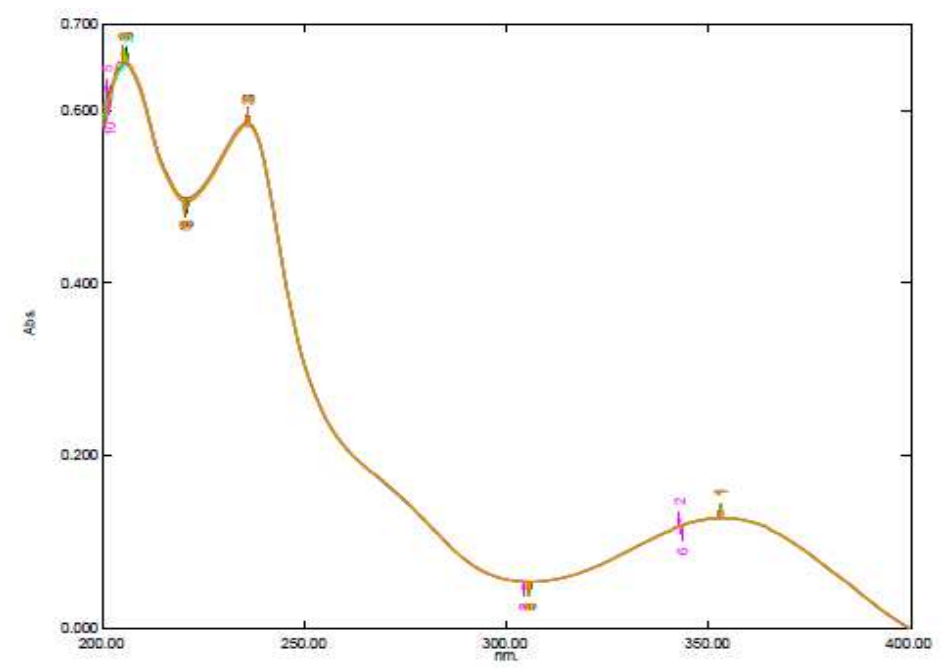

Fig. 3: Overlay UV spectrum at varied scan speed (fast, medium, slow, and very slow) and varied sampling interval (0.1, 0.2, 0.5, 1.0, and 2.0 nm) 
The solvent selection was based on the maximum solubility of BEN. The maximum solubility of BEN was found to be in methanol hence methanol was selected as a solvent for a $U V$ spectrophotometer analytical method of BEN. For all other variable parameters that are shown in Ishikawa diagram, the absorbance spectrums were recorded by scanning standard working solution $(10 \mu \mathrm{g} / \mathrm{ml})$ in the selected solvent from $200-400 \mathrm{~nm}$ in the UV spectrophotometer.

Spectral shape, sharpness, and absorbance intensity of spectrum were recorded and compared at varied scan speed such as fast, medium, slow, and very slow and varied sampling interval was such as of $0.1,0.2,0.5,1.0$, and $2.0 \mathrm{~nm} \mathrm{[17].} \mathrm{As} \mathrm{shown} \mathrm{in} \mathrm{fig.} 3$ spectrums were overlapping each other. Thus, indicating no significant changes in spectral shape, sharpness, and absorbance's intensity of spectrum due to variation in scan speed and sampling interval.

On the basis of above observation, the critical parameters were selected (table 1) and by using selected variable parameters, method is further validated as per the ICH guidelines Q2(R1).

Table 1: Selected critical parameter for spectrophotometric analytical method of BEN

\begin{tabular}{ll}
\hline Parameter & Selected variables \\
\hline Wavelength & $236 \mathrm{~nm}$ \\
Solvent & Methanol \\
Scan speed & Fast \\
Sampling interval & $0.2 \mathrm{~nm}$ \\
\hline
\end{tabular}

\section{Validation}

The selected critical parameters should comply with method performance characteristics of an analytical method in order to achieve analytical target profile of method. ICH has laid down various method performance characteristics for an analytical method in ICH guidelines Q2 (R1). Thus, for a spectrophotometric analytical method, it is appropriate to validating method according to ICH guidelines Q2(R1) on the selected critical parameter in order to implement $\mathrm{AQbD}$ approach.

Hence by using selected critical parameters, developed method is further validated as per the ICH guidelines Q2(R1) [6]. The characteristics studied were system suitability, linearity, precision, accuracy, specificity, limit of detection (LOD) and limit of quantification (LOQ).

\section{System suitability}

System suitability is done to demonstrate the suitability of the UV spectrophotometer system being used for the analysis. Six replicates of standard solution $(10 \mu \mathrm{g} / \mathrm{ml})$ of BEN were prepared from a stock solution in the selected solvent (methanol) and absorbance was determined at $236 \mathrm{~nm}$ of each replicate using UV spectrophotometer. Percentage relative standard deviation (\% RSD) was calculated for the absorbances [6].

\section{Linearity}

According to the ICH guidelines, the linearity of an analytical procedure determines that the test results are directly proportional to the concentration (amount) of analyte in the sample. For linearity study, six solutions of different concentrations $(3,6,9,12,15$ and 18 $\mu \mathrm{g} / \mathrm{ml}$ ) were prepared in methanol from a standard stock solution of BEN and absorbance of each solution was noted at $236 \mathrm{~nm}$ in triplicate. The calibration curve was prepared by plotting the absorbance against concentration and \% RSD, and the correlation coefficient was calculated by regression analysis [6].

\section{Precision}

According to the ICH guidelines, the precision of an analytical procedure determines the closeness of results obtained by multiple measurements of the same homogeneous sample. Repeatability (intra-day precision) and intermediate precision (inter-day precision) were done to show the precision of the method.

To demonstrate repeatability (intra-day precision) of the test method, six replicates of the $10 \mu \mathrm{g} / \mathrm{ml}$ concentration $(\mathrm{n}=6)$ were analyzed on the same day. \% RSD of assay result of six replicates was calculated. Similarly, for intermediate precision (inter-day precision), six replicates of the $10 \mu \mathrm{g} / \mathrm{ml}$ concentrations were analyzed for assay on three consecutive days and \% RSD was calculated [6].

\section{Accuracy}

The accuracy of an analytical procedure shows the closeness of results with the conventional true value. Accuracy was determined by recovery study of BEN. To the known amount of standard solution $(10 \mu \mathrm{g} / \mathrm{ml})$, a known amount of standard stock solution was added at a different level, i.e. $50 \%, 100 \%$. and $150 \%$ to get final concentration of $15 \mu \mathrm{g} / \mathrm{ml}, 20 \mu \mathrm{g} / \mathrm{ml}$, and $25 \mu \mathrm{g} / \mathrm{ml}$. then these solutions were reanalyzed for drug content. Triplicate set of each levels were prepared for the experiment. The recovery of sample, and \% RSD, were calculated [6].

\section{Limit of detection (LOD) and limit of quantification (LOQ)}

Limit of detection is the lowest amount of analyte in a sample that can be detected, but not necessarily quantified as an exact value and limit of quantification is the lowest concentration of an analyte in the sample that can be determined with accuracy and precision. Limit of detection and limit of quantification concentrations for BEN were determined based on the residual standard deviation of response and slope method as per ICH guideline. Calibration curve prepared in linearity study was used for this purpose. For LOD calculation equation $(3.3 \mathrm{x}) / \mathrm{S}$ and for LOQ equation $\left(10 \mathrm{x}^{\boldsymbol{\sigma}}\right) / \mathrm{S}$ was used. Where $\sigma$ is the standard deviation of the response and $\mathrm{S}$ is the slope of the calibration curve [6].

\section{Specificity}

According to ICH guideline specificity is the ability to determine the analyte in the presence of possible components which can be present such as impurities, degradants, excipients, etc. To show specificity spectra of standard solution $(10 \mu \mathrm{g} / \mathrm{ml})$, diluent and common pharmaceutical excipient (oil and surfactant mixture) were compared [6].

\section{RESULTS AND DISCUSSION}

\section{System suitability}

The absorbance of six replicate of standard solution $(10 \mu \mathrm{g} / \mathrm{ml})$ of BEN is reported table 2 . For system suitability \% RSD of absorbance of replicate solutions is should not more than 2 [18]. The results obtained was meets the system suitability requirements, this indicates that the system was suitable for the analysis [19].

\section{Linearity}

The calibration plot of absorbance versus concentration was found to be linear over the concentration range of 3 to $18 \mu \mathrm{g} / \mathrm{ml}$ as shown in fig. 4 and fig. 5. RSD was found to have small value $0.00283 \%$ while correlation coefficient $\left(r^{2}\right)$ have high value 0.9999 (table 3). Thus, indicating that test results were directly proportional to the concentration (amount) of analyte in the sample [20-21].

\section{Precision}

The calculated RSD of intra-day and inter-day precision test are reported in table 4. For a precise analytical method, the \% RSD of assay results of six replicates should not more than 2 . The RSD of the intra-day assay of six replicates was $0.63 \%$ and for interday assay, RSD were $0.82 \%$, $0.98 \%$, and $0.56 \%$ respectively for three consecutive days. Low \% RSD value indicates that method was precise [22-23]. 
Table 2: Result of system suitability studies

\begin{tabular}{ll}
\hline Replicates of standard solution $(\mathbf{1 0} \mu \mathbf{g} / \mathbf{m l})$ of BEN & Absorbance at 236 nm \\
\hline 1 & 0.575 \\
2 & 0.581 \\
3 & 0.572 \\
4 & 0.579 \\
5 & 0.571 \\
6 & 0.577 \\
Mean & 0.575833 \\
SD & 0.00392 \\
RSD & 0.680758 \\
\hline
\end{tabular}

SD-standard deviation, RSD-relative standard deviation

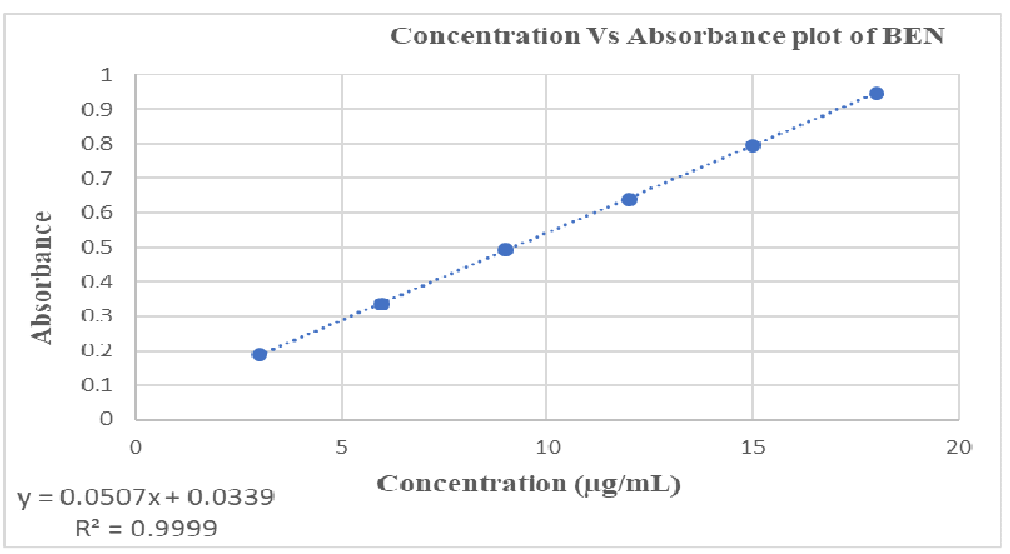

Fig. 4: Calibration curve plot of benidipine hydrochloride at $236 \mathrm{~nm}$

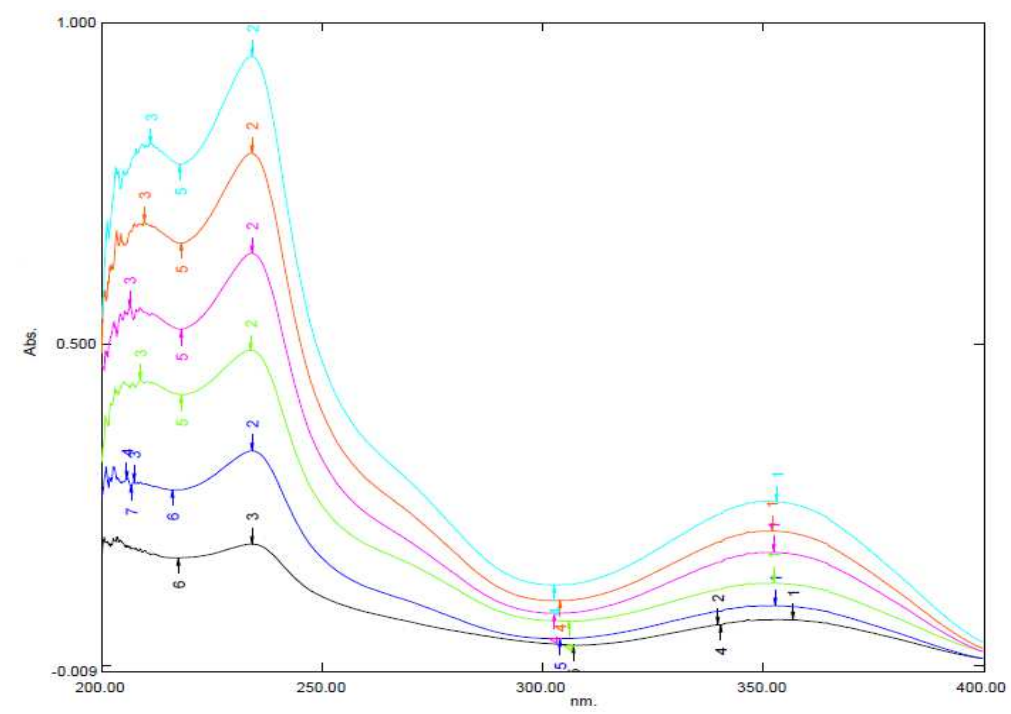

Fig. 5: Overly spectra of benidipine hydrochloride (3 to18 $\mu \mathrm{g} / \mathrm{ml}$ ) at $236 \mathrm{~nm}$

Table 3: Result of linearity study of benidipine hydrochloride

\begin{tabular}{ll}
\hline Concentration $(\boldsymbol{\mu g} / \mathbf{m l})$ & Absorbance* mean \pm SD $(\mathbf{n}=\mathbf{3})$ \\
\hline 3 & $0.189 \pm 0.002$ \\
6 & $0.334 \pm 0.003$ \\
9 & $0.492 \pm 0.001$ \\
12 & $0.640 \pm 0.002$ \\
15 & $0.796 \pm 0.003$ \\
18 & $0.947 \pm 0.003$ \\
$\mathrm{R}^{2}$ & 0.9999 \\
$\%$ RSD & 0.00283 \\
Linear regression equation & $\mathrm{y}=0.0507 \mathrm{x}+0.0339$ \\
\hline
\end{tabular}

${ }^{*}$ mean \pm SD, n=3, SD-standard deviation, RSD-relative standard deviation 
Table 4: Result of precision studies

\begin{tabular}{|c|c|c|c|c|c|c|c|c|c|}
\hline \multicolumn{3}{|c|}{ Intra-day precision (Repeatability) } & \multicolumn{7}{|c|}{ Inter-day precision (Intermediate precision) } \\
\hline \multirow{2}{*}{$\begin{array}{l}\text { Standard } \\
\text { solution } \\
\text { conc. } \\
(\mu \mathrm{g} / \mathrm{ml})\end{array}$} & \multirow{2}{*}{$\begin{array}{l}\text { Conc. found* } \\
(\mu \mathrm{g} / \mathrm{ml}) \\
\text { mean } \pm S D \\
(n=6)\end{array}$} & \multirow[t]{2}{*}{$\%$ RSD } & \multirow{2}{*}{$\begin{array}{l}\text { Standard } \\
\text { solution } \\
\text { conc. } \\
(\mu \mathrm{g} / \mathrm{ml})\end{array}$} & \multirow{2}{*}{$\begin{array}{l}\text { Day } 1 \\
\text { Conc. found* } \\
(\mu \mathrm{g} / \mathrm{ml}) \\
\text { mean } \pm \operatorname{SD}(n=6)\end{array}$} & & \multicolumn{2}{|l|}{ Day 2} & \multicolumn{2}{|l|}{ Day 3} \\
\hline & & & & & \%RSD & $\begin{array}{l}\text { Conc. found* } \\
(\mu \mathrm{g} / \mathrm{ml}) \\
\text { mean } \pm S D(n=6)\end{array}$ & \%RSD & $\begin{array}{l}\text { Conc. found* } \\
(\mu \mathrm{g} / \mathrm{ml}) \\
\text { mean } \pm S D(n=6)\end{array}$ & \%RSD \\
\hline 10 & $10.15 \pm 0.06$ & 0.63 & 10 & $10.13 \pm 0.08$ & 0.82 & $10.17 \pm 0.10$ & 0.98 & $10.09 \pm 0.06$ & 0.56 \\
\hline
\end{tabular}

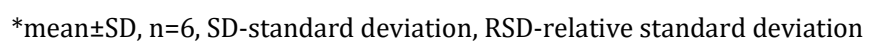

\section{Accuracy}

The purpose of this experiment was to prove the trueness of the assay results obtained by the proposed method. The results of recovery studies are reported in table 5 . The mean recovery was found to be $100.35 \%$ with low RSD value of $1.28(<2 \%)$.

These results demonstrate the accuracy of the method [24-25].

Table 5: Result of accuracy studies

\begin{tabular}{|c|c|c|c|c|c|c|c|}
\hline $\begin{array}{l}\text { Standard solution of } \\
\text { known concentration } \\
(\mu \mathrm{g} / \mathrm{ml})\end{array}$ & $\begin{array}{l}\text { Level of } \\
\text { standard } \\
\text { added } \\
(\%)\end{array}$ & $\begin{array}{l}\text { Amount of } \\
\text { drug added } \\
(\mu \mathrm{g} / \mathrm{ml}) \\
(\mathrm{n}=3)\end{array}$ & $\begin{array}{l}\text { Total amount of } \\
\text { drug found } \\
(\mu \mathrm{g} / \mathrm{ml})^{*} \\
\text { mean } \pm S D(n=3)\end{array}$ & $\begin{array}{l}\text { Amount } \\
\text { recovered } \\
(\mu \mathrm{g} / \mathrm{ml})\end{array}$ & $\begin{array}{l}\% \\
\text { recovery }\end{array}$ & $\begin{array}{l}\text { Mean \% recovery of } 3 \\
\text { levels }(50 \%, 100 \% \text {, } \\
150 \%)\end{array}$ & $\begin{array}{l}\% \\
\text { RSD }\end{array}$ \\
\hline \multirow[t]{4}{*}{10} & 0 & 0 & $9.92 \pm 0.10$ & 9.92 & - & - & - \\
\hline & 50 & 5 & $15.01 \pm 0.17$ & 5.09 & 101.8 & 100.35 & 1.28 \\
\hline & 100 & 10 & $19.91 \pm 0.18$ & 9.99 & 99.89 & & \\
\hline & 150 & 15 & $24.97 \pm 0.34$ & 15.05 & 99.36 & & \\
\hline
\end{tabular}

*mean \pm SD, n=3, SD-standard deviation, RSD-relative standard deviation

\section{Limit of detection (LOD) and limit of quantification (LOQ)}

By using calibration curve, the standard deviation of the response $(\sigma)$ and slope of the calibration curve (S) was determined and calculation was carried out using equations $(3.3 \times \boldsymbol{\sigma}) / \mathrm{S}$ for LOD and $\left(10 \times{ }^{\sigma}\right) / S$ for LOQ. The LOD was found to be $0.20 \mu \mathrm{g} / \mathrm{ml}$ and the LOQ was found to be $0.60 \mu \mathrm{g} / \mathrm{ml}$. Results are reported in table
6. These results indicated the high sensitivity of the proposed UV method [26].

\section{Specificity}

For a specific analytical method, there should be no interfering peak of diluent and possible excipient with the analyte [27]. Fig. 6 shows that no interfering peaks were observed during analysis. Hence method was specific.

Table 6: Limit of detection (LOD) and limit of quantification (LOQ) determination

\begin{tabular}{ll}
\hline Parameter & Observed value \\
\hline Slope of regression $(\mathrm{S})$ & 0.0507 \\
Residual standard deviation $(\boldsymbol{\sigma})$ & 0.003046 \\
LOD concentration $(\mu \mathrm{g} / \mathrm{ml})$ & 0.20 \\
LOQ concentration $(\mu \mathrm{g} / \mathrm{ml})$ & 0.60 \\
\hline
\end{tabular}

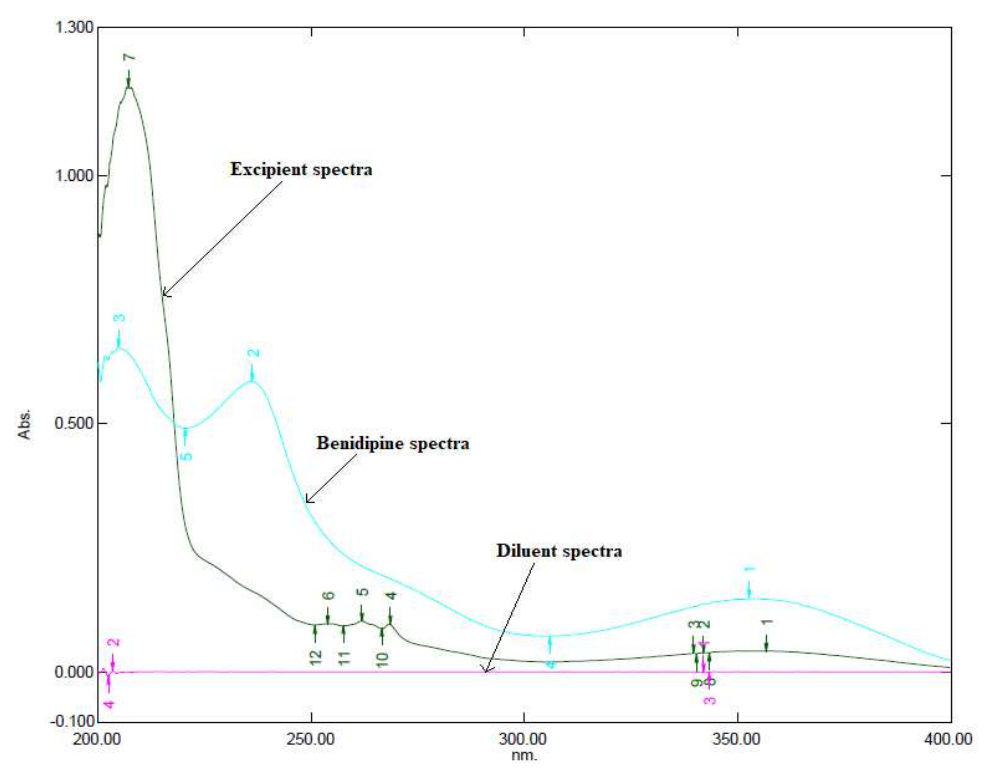

Fig. 6: Specificity studies by comparing the spectra of benidipine hydrochloride, possible pharmaceutical excipient, and diluent (solvent) 


\section{CONCLUSION}

A simple, rapid, sensitive, accurate, precise and inexpensive spectrophotometric method was developed for estimation of benidipine hydrochloride in bulk by using analytical quality by design" (AQbD) approach. On the basis of an investigation of the effect of method input variables on absorbance pattern, the critical parameters have been selected for proposed method and it was further validated as per the ICH guidelines. The developed method does not involve complexity thus have an economic advantage over common chromatographic methods. Therefore, developed spectrophotometric method can be used flexibly and efficiently for the determination of benidipine either in bulk or in the dosage formulations.

\section{ACKNOWLEDGMENT}

The corresponding author acknowledges University Grants Commission (UGC), Government of India, for the Junior Research Fellowship [UGC-NET JRF Award, F.15-6(DEC.2013)/2014(NET)].

\section{AUTHORS CONTRIBUTIONS}

All the authors have contributed equally

\section{CONFLICTS OF INTERESTS}

Declared none

\section{REFERENCES}

1. Kitakaze M, Karasawa A, Kobayashi H, Tanaka H, Kuzuya T, Hori M. Benidipine: a new Ca 2+channel blocker with a cardioprotective effect. Cardiovasc Drug Rev 1999;17:1-15.

2. Rozet E, Ziemons E, Marini RD, Boulanger B, Hubert P. Quality by design compliant analytical method validation. Anal Chem 2012;84:106-12.

3. ICH Expert Working Group. ICH Harmonised Tripartite Guideline-Pharmaceutical development Q8 (R2). In: Current Step 4 version; 2009. p. 1-28.

4. ICH Expert Working Group. ICH Harmonised Tripartite Guideline-Quality risk management Q9. In: Current Step 4 version; 2005. p. 1-23.

5. ICH Expert Working Group. ICH Harmonised tripartite guideline-pharmaceutical quality system Q10. In: Current Step 4 version; 2008. p. 1-21.

6. ICH Expert Working Group. ICH Harmonised Tripartite Guideline-Validation of analytical procedures: Text and methodology Q2(R1). In: Current Step 4 version; 2005. p. 1-17.

7. McCurdy V. Quality by design. In: Houson I, editor. Process understanding: For scale-up and manufacture of active ingredients. First Edit. Wiley-VCH Verlag GmbH and Co. KGaA; 2011. p. 1-16.

8. Lloyd DK, Bergum J. Application of quality by design (QbD) to the development and validation of analytical methods. In: Riley CM, Rosanske TW, Riley SRR. editors. Specification of drug substances and products: Development and validation of analytical methods. Elsevier; 2014. p. 29-72.

9. Schweitzer $M$, Pohl $M$, Hanna-Brown $M$, Nethercote $P$, Bormanare P, Hansen G, et al. Implications and opportunities of applying QbD principles to analytical measurements. Pharm Technol 2010;34:12-9.

10. Vogt FG, Kord AS. Development of quality-by-design analytical methods. J Pharm Sci 2011;100:797-812.

11. Musters J, Van Den Bos L, Kellenbach E. Applying QbD principles to develop a generic UHPLC method which facilitates continual improvement and innovation throughout the product lifecycle for a commercial API. Org Proc Res Dev 2013;17:87-96.
12. Hanna Brown M, Borman P, Bale S, Szucs R, Roberts J, Jones C. Development of chromatographic methods using $\mathrm{QbD}$ principles. Sep Sci 2010;2:10-2.

13. Ling S, McBrien MA. Quality by design approach to chromatographic method development. LCGC Column 2011;7:16-20.

14. Bhatt DA, Rane SI. QbD approach to analytical RP-HPLC method development and its validation. Int J Pharm Pharm Sci 2011;3:179-87.

15. Karmarkar S, Yang X, Garber R, Szajkovics A, Koberda M. Quality by design (QbD) based development and validation of an HPLC method for amiodarone hydrochloride and its impurities in the drug substance. J Pharm Biomed Anal 2014;100:167-74.

16. Peraman R, Bhadraya K, Padmanabha Reddy Y. Analytical quality by design: a tool for regulatory flexibility and robust analytics. Int J Anal Chem 2015:1-9. http://dx.doi.org/ $10.1155 / 2015 / 868727$.

17. Jadhav ML, Tambe SR. Implementation of QbD approach to the analytical method development and validation for the estimation of propafenone hydrochloride in tablet dosage form. Chromatogr Res Int 2013:1-9. http://dx.doi.org/10.1155/ 2013/676501.

18. Behera S, Ghanty S, Ahmad F, Santra S, Banerjee S. UV-Visible spectrophotometric method development and validation of assay of paracetamol tablet formulation. J Anal Bioanal Tech 2012;3:1-6.

19. Martins LG, Khalil NM, Mainardes RM. Application of a validated HPLC-PDA method for the determination of melatonin content and its release from poly (lactic acid) nanoparticles. J Pharm Anal 2017;7:388-93.

20. Singh S, Sharma N, Singla YP, Arora S. Development and validation of UV-spectrophotometric method for quantitative estimation of nefopam hydrochloride in polymethacrylate nanospheres. Int J Pharm Pharm Sci 2016;8:414-9.

21. Ibrahim F, Wahba MEK, Magdy G. Analytical method development and validation of spectrofluorimetric and spectro-photometric determination of some antimicrobial drugs in their pharmaceuticals. Spectrochim Acta Part A Mol Biomol Spectrosc 2018;188:525-36.

22. Chakravarthy A, Sailaja BB, Kumar P. Method development and validation of ultraviolet-visible spectroscopic method for the estimation of assay of sugammadex sodium, apremilast, riociguat, and vorapaxar sulfate drugs in active pharmaceutical ingredient form. Asian J Pharm Clin Res 2017;10:241-50.

23. Sai Pavan Kumar B, Mathrusri Annapurna M, Pavani S. Development and validation of a stability indicating RP-HPLC method for the determination of rufinamide. J Pharm Anal 2013;3:66-70.

24. Kaur T, Kaur S, Kaur P. Development and validation of UVspectrophotometric methods for determination of gemcitabine hydrochloride in bulk and polymeric nanoparticles. Int J Appl Pharm 2017;9:60-5.

25. Kaur S, Bala I, Anjoo Kamboj A, Jain UK. Development and validation of analytical method for estimation of aripiprazole in swab samples on pharmaceutical manufacturing equipment surfaces for cleaning validation. Int J Pharm Pharm Sci 2017;9:141-51.

26. Prasad AR, Thireesha B. UV-spectrophotometric method development and validation for the determination of lornoxicam in microsponges. Int J Appl Pharm 2018;10:74-8.

27. Pani NR, Nath L, Singh AV, Mahapatra SK. Development and validation of analytical method for the estimation of nateglinide in rabbit plasma. J Pharm Anal 2012;2:492-8. 